\title{
Spawning strategy in Atlantic bobtail squid Sepiola atlantica (Cephalopoda: Sepiolidae)
}

\author{
Marcelo Rodrigues • Manuel E. Garcí • \\ Jesús S. Troncoso • Ángel Guerra
}

Received: 20 November 2009 / Revised: 18 March 2010 / Accepted: 19 March 2010 / Published online: 6 April 2010

(C) Springer-Verlag and AWI 2010

\begin{abstract}
This study aimed to determine the spawning strategy in the Atlantic bobtail squid Sepiola atlantica, in order to add new information to the knowledge of its reproductive strategy. A total of 12 females that spawned in aquaria were examined. Characteristics of the reproductive traits and egg clutches were similar to those of other known Sepiolidae. Clutch size varied from 31 up to 115 eggs. Females of this species had incorporated up to 1.58 times of their body weight into laid eggs. The size of laid eggs showed a positive correlation with maternal body size, supporting the idea that female size is a determinant of egg size. Our data suggest that $S$. atlantica is an intermittent terminal spawner, and that its spawning strategy comprises group-synchronous ovary maturation, multiple egg laying, and deposition of egg clutches in different locations. The obtained data provide insights for future comparative studies on reproductive allocation.
\end{abstract}

Keywords Spawning strategy $\cdot$ Egg size $\cdot$ Reproduction . Sepiola atlantica

Communicated by H.-D. Franke.

M. Rodrigues $(\square) \cdot$ J. S. Troncoso

Departamento de Ecología y Biología Animal,

Universidad de Vigo, 36310 Vigo, Pontevedra, Spain

e-mail: marcelorodrigues@uvigo.es

M. E. Garcí · Á. Guerra

ECOBIOMAR, Instituto de Investigaciones Marinas,

CSIC, Vigo, Spain

\section{Introduction}

Cephalopods have highly variable and complex life history traits related to reproduction (Hanlon and Messenger 1996). Information on reproductive strategies may lead to a better understanding of the evolution of life histories, both reproductive strategies and life cycles being genetic adaptations to optimize the use of ecological niches in direct competition with other species and in response to environmental conditions (Rocha et al. 2001). The patterns of ovulation and spawning are basic elements to characterize cephalopod reproductive patterns.

Ovulation patterns may be distinguished according to oocyte formation and development and are strongly correlated with spawning patterns (see Rocha et al. 2001; Nigmatullin 2002). Among the spawning patterns defined by Rocha et al. (2001) are multiple spawning and intermittent terminal spawning. According to these authors, spawning in the former pattern is monocyclic and eggs are laid in separate batches, with somatic growth continuing between separate events. The intermittent terminal spawning differs from multiple spawning in that somatic growth does not take place between spawning events.

Field data on spawning and eggs are difficult to obtain and often difficult to interpret, due to the type of spawning pattern (Rocha et al. 2001) or problems in species identification from egg masses (Boletzky 1998). Therefore, direct observations on aquarium-kept females can be instructive and have been recorded for decades (e.g. Bello and Deickert 2003; Boletzky et al. 1971; Gabel-Deickert 1995; Nabhitabhata et al. 2005). Direct aquarium observations have revealed that the bobtail squids Sepiola affinis, Sepiola rondeleti, Sepiola intermedia, Sepietta obscura, and Sepietta sp. are intermittent spawners (Gabel-Deickert 1995), and that Sepietta oweniana is a multiple spawner (Bello and 
Deickert 2003). However, little is known about the life history of the Atlantic bobtail squid Sepiola atlantica d'Orbigny 1839-1842 (Guerra 1992; Reid and Jereb 2005; Rodrigues et al. 2009; Yau and Boyle 1996; van Moorsel 2004).

Sepiola atlantica is widely distributed in the northeastern Atlantic from latitudes $65^{\circ} \mathrm{N}-35^{\circ} \mathrm{N}$ from areas around Iceland, the Faroe Islands, the Norwegian Sea, the United Kingdom, the North Sea, France, the Iberian Peninsula, and the northwestern coast of Africa to Morocco (Reid and Jereb 2005). Its ecology has been studied by Yau and Boyle (1996) in the West coast of Scotland. Although this species was considered to be a resident species, the authors were not able to find egg masses. The only report of egg masses in British waters is by Bidder (in Rees 1957). This author reported egg masses collected in the field on bryozoans of the genus Cellaria Ellis and Solander 1786. Unfortunately, this paper provides little information on egg size, actual fecundity, spawning pattern, spawning clutch size, and time of spawning in S. atlantica.

As in other sepiolids, in S. atlantica, spermatophores are transferred to females and stored in the bursa copulatrix, a large pouch lying on the visceral mass that allows the spermatangia to become attached (Rodrigues et al. 2009; Yau and Boyle 1996). They can remain there for long periods of time until eggs are laid and fertilized. Fertilization is probably achieved when eggs transverse the bursa copulatrix (Hanlon and Messenger 1996). It is thus interesting to check whether females stop spawning once spermatangia have been used up.

The present investigation follows the methodology suggested by Rocha et al. (2001), and the analyses are based on the three factors considered by these authors: type of ovulation, spawning pattern, and growth vs. lack of growth between egg-laying events. Additionally, we have introduced novel characters in the analysis such as egg clutch, egg size, and indexes to assess the reproductive allocation that allow us to discuss ecological features of the spawning strategy in greater detail.

The aim of this work is therefore to add new information to the knowledge of the reproductive strategy of $S$. atlantica through direct observation of specimens in captivity, and to compare these patterns with those known of other members of the family Sepiolidae.

\section{Materials and methods}

This investigation was carried out between March 2008 and July 2009. A total of 12 adult females were collected by scuba diving during several field trips in the Ría de Vigo $\left(42^{\circ} 14^{\prime} \mathrm{N} ; 8^{\circ} 47^{\prime} \mathrm{W}\right)$, NW Iberian Peninsula. Depth of collections ranged from 3.5 to $8 \mathrm{~m}$, and the seabed was sandy with the presence of ripplemarks and without algal cover.

Live specimens were immediately and carefully transported to the Marine Station of the University of Vigo in Toralla Island (ECIMAT-UVIGO). Each individual was placed in a $10.21(30 \mathrm{~cm}$ long $\times 18 \mathrm{~cm}$ wide $\times 19 \mathrm{~cm}$ deep) glass tank with an open system of running seawater. Water temperature in the tanks ranged between 13 and $19.5^{\circ} \mathrm{C}$. The system received natural photoperiod according to the season. The bottom of the tanks was covered with a thin $(1-2 \mathrm{~cm})$ layer of fine sand, taken from the same locality where the specimens were collected. All tanks were provided with local bivalve shells to serve as a substrate for egg deposition. Females were always kept in isolation in the tanks and were never exposed to males in captivity, but all of them produced eggs that initiated development, thus indicating that spermatangia were present in the females.

Bobtail squids were fed daily ad libitum with adults of the local mysid shrimp Siriella armata. After the first episode of egg laying and up to death, the bobtail squids were offered ten S. armata daily, and intake was controlled daily. Feeding rate was calculated according to Choe (1966): $\mathrm{FR}=[F /(t \mathrm{BW})] \times 100$, where FR is the feeding rate (percentage per day), $F$ is total food consumed in wet weight, $\mathrm{BW}$ is body weight, and $t$ is the number of days.

Daily routine controls were undertaken between 09:00 and 10:00 a.m., allowing to record for each individual: egg number per clutch, spawning duration (time from first to last egg laid), actual fecundity ( $\mathrm{AF}=$ total number of eggs laid by a female), and food intake during spawning. Daily controls were carried out until death, up to 20 days after the first egg-laying episode. Spawning was observed in different months during the current study, and no preference was observed in terms of spawning season.

Specimens were measured for dorsal mantle length (ML) to $0.01 \mathrm{~mm}$ accuracy, weighed (BW) to $0.00001 \mathrm{~g}$ immediately after death, and subsequently preserved in $70 \% \mathrm{EtOH}$. All dissections were made on preserved specimens.

All immature and mature oocytes from the ovary and the proximal oviduct were counted and measured along the major axis using a stereomicroscope (Nikon SMZ-1500) directly connected to a computer with an image analyzer (Nikon, NIS-Elements). Based on indications given by Mangold-Wirz (1963), oocytes were assigned to four classes, depending on their stage of development: (1) early follicle oocytes (small, $0.09-1.67 \mathrm{~mm}$ ); (2) late follicle oocytes without striated surface (medium, $1.68-2.53 \mathrm{~mm}$ ); (3) yolky oocytes with white and striated surface (large); and (4) mature oocytes with smooth surface and orange in color. The size of the two last categories ranged from 2.54 to $3.75 \mathrm{~mm}$.

The potential fecundity (PF) was expressed as the sum of the numbers of oocytes in the ovary and the oviduct plus 
the number of eggs already spawned. For assessing the reproductive allocation for each female, we determined two indexes: (1) The Relative Egg Capsule Length (REL), which was calculated as the ratio between mean egg capsule length in the major axis and ML, and (2) The Relative Egg Capsule Weight (REW) as the ratio between mean egg capsule weight and BW.

Additionally, after the last laying episode, all eggs were carefully removed from the substrate, measured, and weighed as indicated above. The egg volume was approximated using the formula for the volume of a prolate ellipsoid, (4/3) $\pi \mathrm{LW}^{2}$ (within $0.01 \mathrm{~mm}^{3}$ ) (Beyer 1987), where $L=$ egg length $(\mathrm{mm})$ and $W=$ egg width $(\mathrm{mm})$.

Table 1 S. atlantica. Dorsal mantle length (ML, mm), body weight (BW, g), and spawning events for each female analyzed in this study

\begin{tabular}{llllll}
\hline Female & ML & BW & $\begin{array}{l}\text { Number } \\
\text { of events }\end{array}$ & $\begin{array}{l}\text { Spawning } \\
\text { duration } \\
\text { (days) }\end{array}$ & $\begin{array}{l}\text { Major and } \\
\text { minor spawning } \\
\text { batch size }\end{array}$ \\
\hline 1 & 12.19 & 0.76 & 3 & 6 & $50-3$ \\
2 & 12.66 & 0.63 & 3 & 3 & $36-2$ \\
3 & 11.62 & 0.92 & 2 & 3 & $58-2$ \\
4 & 16.01 & 0.89 & 3 & 7 & $47-2$ \\
5 & 12.21 & 1.38 & 2 & 2 & $50-2$ \\
6 & 16.07 & 1.05 & 3 & 13 & $34-5$ \\
7 & 19.54 & 1.60 & 7 & 20 & $8-2$ \\
8 & 11.98 & 1.04 & 9 & 12 & $42-1$ \\
9 & 12.50 & 0.58 & 2 & 3 & $22-5$ \\
10 & 14.55 & 1.30 & 3 & 4 & $60-5$ \\
11 & 15.33 & 1.40 & 6 & 11 & $89-1$ \\
12 & 15.01 & 1.01 & 2 & 4 & $31-4$ \\
\hline
\end{tabular}

\section{Results}

\section{Spawning}

Before females started to spawn, they were maintained in captivity between 51 and 137 days. Unfortunately, no spawning event was directly observed. All spawning episodes took place at night. The females were always found dying or already dead in the morning. The observations of the timing of spawning events and spawning duration in the 12 studied females are shown in Table 1 . The females did not take care of their egg clutches after spawning. No female survived more than a day after the last egg-laying event, and death does not seem to be related to the exhaustion of reproductive potential (Table 2).

Eggs capsules are opaque, orange, and droplet-shaped (Fig. 1a, b). The capsules were laid either in a single layer or piled up into clusters of several layers. In all observed spawning events, the first egg batches were deposited at the water surface of the tank, and the following batches were attached to the walls of the tank, to the PVC pipe (drain), or to the sandy bottom (Fig. 1c), but never to the presented bivalve shells. Sometimes these batches were deposited on the top of previously laid batches and occasionally above the water surface. Individual batches contained between 1 and 89 eggs (Table 1). In all females, we observed multiple egg batches laid at intervals of roughly 1-8 days. In 11 of 12 females, the first batch of eggs was the largest one. After the second batch, the number of laid eggs was reduced in all females.

Females 2, 4, 8, and 9 (Table 1) laid some incompletely encapsulated eggs. This phenomenon always occurred in the last two batches of eggs.

Table 2 S. atlantica. Reproductive output of the 12 females analyzed in this study

\begin{tabular}{|c|c|c|c|c|c|c|}
\hline \multirow[t]{2}{*}{ Female } & \multicolumn{3}{|c|}{ Immature oocytes (\%/number) } & \multirow{2}{*}{$\begin{array}{l}\text { Mature oocytes } \\
(2.68-3.75 \mathrm{~mm})\end{array}$} & \multirow{2}{*}{$\begin{array}{l}\text { Actual } \\
\text { fecundity }\end{array}$} & \multirow{2}{*}{$\begin{array}{l}\text { Potential } \\
\text { fecundity }\end{array}$} \\
\hline & $\begin{array}{l}\text { Small } \\
(0.09-1.67 \mathrm{~mm})\end{array}$ & $\begin{array}{l}\text { Medium } \\
(1.68-2.53 \mathrm{~mm})\end{array}$ & $\begin{array}{l}\text { Large } \\
(2.54-3.75 \mathrm{~mm})\end{array}$ & & & \\
\hline 1 & $85.9 / 153$ & $13.5 / 24$ & $0.6 / 1$ & 9 & 69 & 256 \\
\hline 2 & $80.8 / 122$ & $17.9 / 27$ & $1.3 / 2$ & 12 & 54 & 217 \\
\hline 3 & $93.0 / 106$ & $6.1 / 7$ & $0.9 / 1$ & 17 & 60 & 191 \\
\hline 4 & $86.0 / 87$ & $11.0 / 10$ & $3.0 / 3$ & 7 & 49 & 165 \\
\hline 5 & $84.8 / 190$ & $11.6 / 26$ & $3.6 / 8$ & 28 & 52 & 304 \\
\hline 6 & $79.3 / 178$ & $19.9 / 46$ & $0.8 / 2$ & 11 & 58 & 300 \\
\hline 7 & $71.7 / 164$ & $25.7 / 59$ & $2.6 / 6$ & 21 & 31 & 281 \\
\hline 8 & $75.0 / 63$ & $23.8 / 20$ & $1.2 / 1$ & 0 & 111 & 195 \\
\hline 9 & $91.0 / 178$ & $8.0 / 16$ & $1.0 / 2$ & 0 & 54 & 250 \\
\hline 10 & $81.0 / 160$ & $18.5 / 37$ & $0.5 / 1$ & 5 & 72 & 274 \\
\hline 11 & 81.0/98 & $17.4 / 21$ & $1.6 / 2$ & 2 & 115 & 228 \\
\hline 12 & $91.6 / 76$ & $4.8 / 4$ & $3.6 / 3$ & 1 & 35 & 119 \\
\hline
\end{tabular}




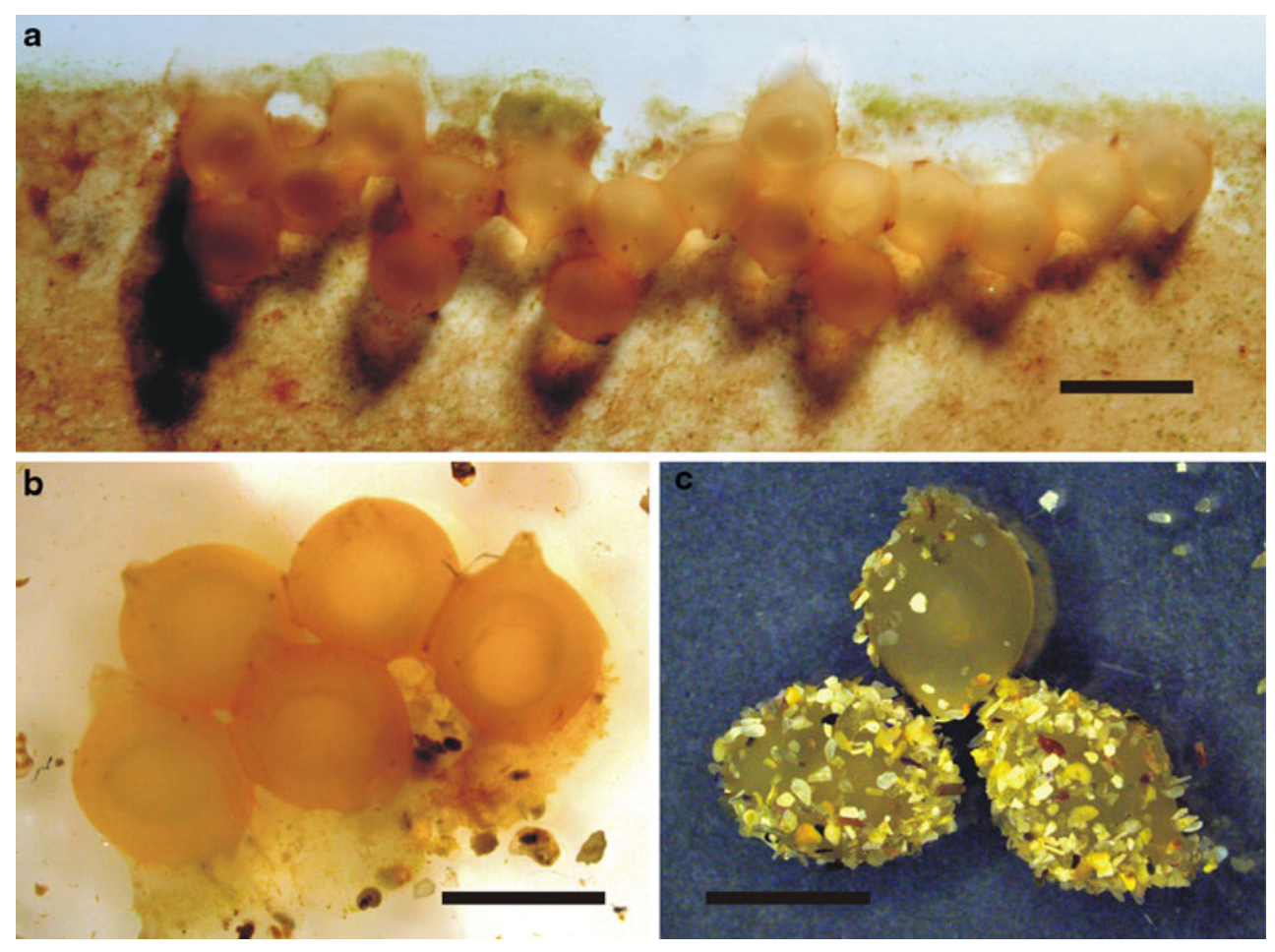

Fig. 1 S. atlantica. Egg capsules laid in an aquarium. a Batch of eggs attached to an aquarium wall just below the water surface; $\mathbf{b}$ egg capsules attached laterally to one another; $\mathbf{c}$ egg capsules laid individually

No female fasted during spawning. Food intake during spawning was between 0.14 and $0.29 \mathrm{~g} \mathrm{day}^{-1}$ (mean $0.22 \pm 0.05 \mathrm{~g} \mathrm{day}^{-1}$ ) or between 12.5 and $31.1 \% \mathrm{BW}_{\text {day }}{ }^{-1}$ (mean $21.7 \% \pm 6.3 \mathrm{BW} \mathrm{day}^{-1}$ ). No dissected female showed spermatangia attached in the bursa copulatrix.

\section{Fecundity}

The ovulation pattern in S. atlantica was group-synchronous (see Rocha et al. 2001). This was revealed through the mature oocytes, represented as AF, that have been spawned, while another group of oocytes is represented by small protoplasmic oocytes in the ovary of spent females (Harman et al. 1989). Post-spawning females exhibited eggs in different stages of protoplasmic growth and yolk accumulation, with a predominance (71.7-93.0\%) of small oocytes of $0.09-1.68 \mathrm{~mm}$ (Table 2). The size of immature oocytes (small, medium and large) varied between 0.09 and $3.75 \mathrm{~mm}$ (mean $0.87 \pm 0.55 \mathrm{~mm}$ ). Of the 12 spawning females, 10 contained up to 28 mature oocytes in the oviduct at death (Table 2), varying in size between 2.68 and $3.75 \mathrm{~mm}$ (mean $2.75 \pm 0.44 \mathrm{~mm}$ ). The largest oocytes were found in the largest females.

The AF varied from 31 to 115 eggs and the PF from 119 to 304 (Table 2). REL ranged from 16 up to $23 \% \mathrm{ML}$ (mean $19 \pm 2 \% \mathrm{ML}$ ). The females incorporated (REW) between 0.37 and 1.58 (mean $0.79 \pm 0.36 \% \mathrm{BW}$ ) times on the sand bottom, and covered with sand grains. Scale bars: $7 \mathrm{~mm}(\mathbf{a})$, $3 \mathrm{~mm}(\mathbf{b}, \mathbf{c})$

their BW into reproductive material spawned (laid eggs). The number of laid eggs did not show any correlation with the number of oocytes, and mature ova remained within the ovary $(P>0.05)$. The size of the egg capsules in the major axis was $1.75-4.92 \mathrm{~mm}$ (mean $2.75 \pm 0.44 \mathrm{~mm}$ ).

Egg volume ranged between 22.20 and $246.72 \mathrm{~mm}^{3}$ (mean $75.89 \pm 31.56 \mathrm{~mm}^{3}$ ). The relationship between ML and Egg Volume (EV) led to a weak linearized calibration function $\left(R^{2}=0.646, P<0.01\right)$ (Fig. 2). The regression equation was: $\mathrm{ML}=8.8256+0.0746 \mathrm{EV}$. The weights of laid eggs ranged between 0.0036 and $0.0252 \mathrm{~g}$ (mean $0.0072 \pm 0.0041 \mathrm{~g}$ ). Of the best-fit, ML against Egg Weight (EW) resulted in a non-linear third-order polynomial function $\left(R^{2}=0.865, P<0.001\right)$ (Fig. 3). The regression equation was: $\mathrm{ML}=1883.4 \mathrm{EW}-140529.7 \mathrm{EW}^{2}+$ 4660521.9EW +5.937 . Clutch size did not show any correlation with egg volume $(P>0.05)$ or egg weight $(P>0.05)$.

\section{Discussion}

Our observations suggest that $S$. atlantica is an intermittent terminal spawner (see Rocha et al. 2001; Nigmatullin 2002). To avoid any disturbance of spawning behavior, in the present study, no measurements were performed to find out whether there is somatic growth between egg batches. 


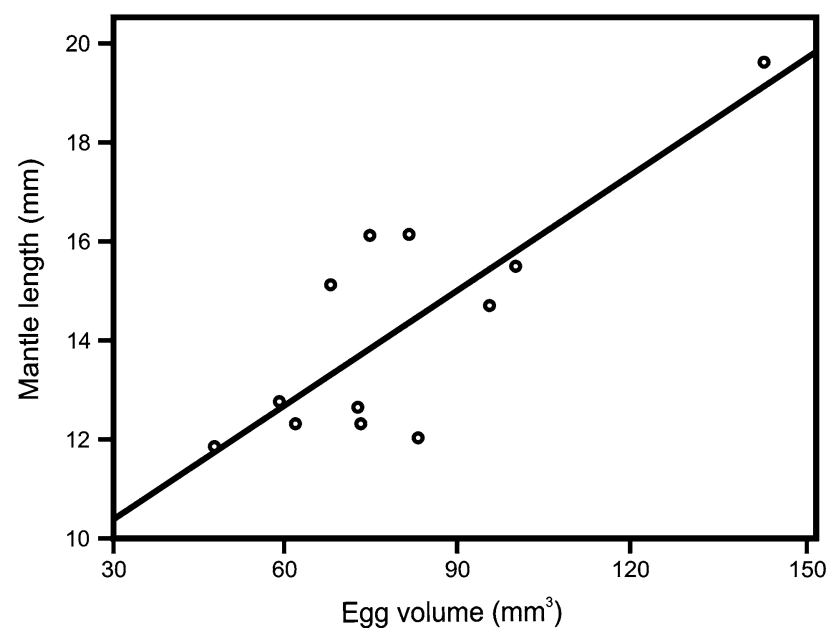

Fig. 2 S. atlantica. Relationship between egg volume and dorsal mantle length fitted by a linearized calibration function

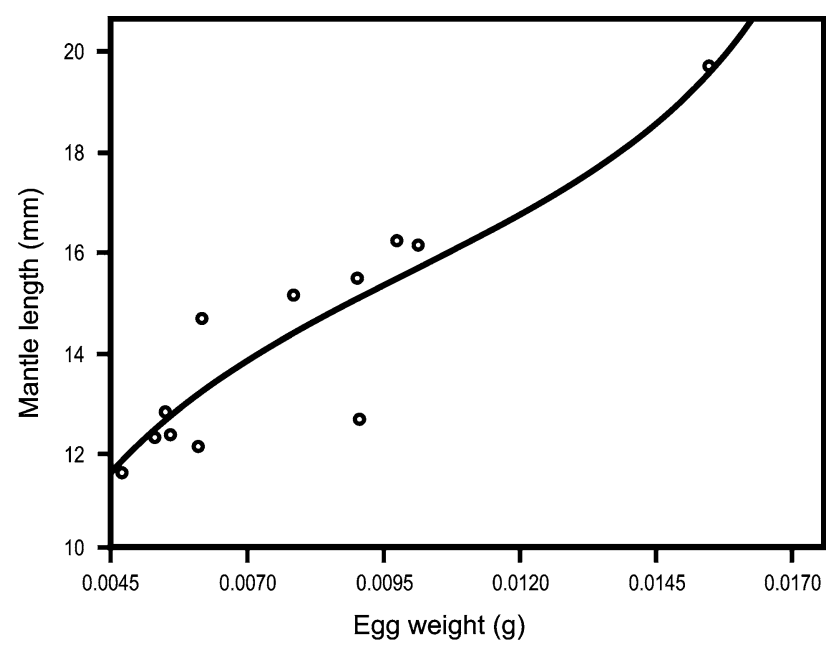

Fig. 3 S. atlantica. Relationship between egg weight and dorsal mantle length fitted by a non-linear third-order polynomial calibration function

The presence of different-sized oocytes in the ovary indicated that the ovulation pattern is group-synchronous in this species. Presence of oocytes in different stages of maturity in S. atlantica has been reported for Scottish waters by Yau and Boyle (1996). The mean diameter of mature oocytes measured in our study was similar to that presented by Yau and Boyle (1996): $2.75 \pm 0.44 \mathrm{~mm}$ and 2.5-3.0 mm, respectively. As no size distributions were given in the latter study, a proper comparison cannot be made. On the other hand, this study showed that females of $S$. atlantica as well as those of other bobtail squids do not spawn daily (Bello and Deickert 2003; Gabel-Deickert 1995), and that each batch of eggs might represent the daily production of mature oocytes or an appropriate time lapse between egg batches. This production decreased throughout the spawning period until death. However, the fact that $S$. atlantica can lay multiple batches of eggs at least over a period of 20 days does not prove that this capacity is always fully exploited under natural conditions. Moreover, as reproduction requires considerable allocation of energy, the presence of a relatively small number of medium and large oocytes in the ovary (Table 2) could suggest that the energy provided through food intake was directed toward egg formation, while somatic growth did not take place, which is characteristic of this spawning strategy. However, results on some other species of bobtail squid suggest the opposite, i.e. a continuing increase in female body size once spawning has been initiated (Bello and Deickert 2003; Boletzky 1975).

We did not find spermatangia attached to the bursa copulatrix in any female after death, but mature ova were observed in the ovary, indicating that adult females may stop laying eggs once the spermatangia have been used up. The fact that eggs were deposited without exposing the isolated females to males indicates that females do not require the presence of males to lay eggs. Little is known on mating systems and social interactions between male and female bobtail squids (Hanlon and Messenger 1996; Rodrigues et al. 2009). Although a misbalance of mating systems could influence egg laying, resulting in poor egg production (Hanlon and Messenger 1996; Hanlon et al. 1997), we were not able to evaluate this in our study.

The timing of spawning within the diel cycle in $S$. atlantica was similar to that of other studied bobtail squids such as Sepiola robusta, Sepiola ligulata, and S. rondeleti (Boletzky et al. 1971) and differs from that of Euprymna scolopes, which spawns in the morning (Hanlon et al. 1997).

Egg capsule morphology of $S$. atlantica was similar to that of other sepiolid species (Boletzky 1998; Nabhitabhata et al. 2005). In this study, S. atlantica deposited eggs on different substrates available in the tank. A similar finding was reported by Boletzky et al. (1971) for five Mediterranean bobtail squids. Additionally, the authors mentioned that $S$. rondeleti deposited a larger number of eggs on the sand bottom, as observed in this study. In the same way, Arnold et al. (1972) and Hanlon et al. (1997) reported the presence of a coating of sand grains and small bits of coral in both field-collected and laboratory-spawned E. scolopes eggs. Another interesting aspect observed in $S$. affinis by Gabel-Deickert (1995) as well as in S. atlantica (present study) is the deposition of eggs on the top of previous batches. However, in the former species, there was no information on whether the eggs were exposed to air as observed in S. atlantica. The deposition of eggs in multiple clutches and in different locations makes respective field studies difficult (no sepiolid eggs were found in any of our dives) and stresses the importance of laboratory observations. 
Table 3 Comparison with other bobtail squid species for which laboratory observations exist

\begin{tabular}{|c|c|c|c|c|}
\hline Species & $\begin{array}{l}\text { Egg volume } \\
\left(\mathrm{mm}^{3}\right)\end{array}$ & $\begin{array}{l}\text { Actual } \\
\text { fecundity }\end{array}$ & $\begin{array}{l}\text { Spawning } \\
\text { duration (days) }\end{array}$ & Reference \\
\hline Sepiola atlantica & $22.20-246.72$ & $31-115$ & $2-20$ & Present study \\
\hline Sepiola affinis & 29.53 & $25-349$ & $1-61$ & $\begin{array}{l}\text { Boletzky (1975), } \\
\text { Gabel-Deickert (1995) }\end{array}$ \\
\hline Sepiola rondeleti & - & 302 & 31 & Gabel-Deickert (1995) \\
\hline Sepiola intermedia & - & $47-184$ & $1-15$ & Gabel-Deickert (1995) \\
\hline Sepietta obscura & - & 428 & 15 & Gabel-Deickert (1995) \\
\hline Sepietta sp. & 130.00 & 233 & 13 & Gabel-Deickert (1995) \\
\hline Sepietta oweniana & - & $76-428$ & $2-21$ & $\begin{array}{l}\text { Gabel-Deickert (1995), } \\
\text { Bergström and Summers (1983), } \\
\text { Bello and Deickert (2003) }\end{array}$ \\
\hline Euprymna hyllebergi & - & $108-464$ & $40-60$ & Nabhitabhata et al. (2005) \\
\hline Euprymna tasmanica & - & $100-146$ & N/D & Norman and Lu (1997) \\
\hline
\end{tabular}

As observed in other representatives of the family Sepiolidae maintained in captivity, $S$. atlantica generally presented an AF within the same range observed in other representatives of the family Sepiolidae maintained in captivity (Table 3). Egg volume in S. atlantica varied significantly according to maternal body size.

The data on egg volume in S. affinis and Sepietta $\mathrm{sp}$ (Table 3) cannot properly be compared with those presented for $S$. atlantica as the formula used by Gabel-Deickert (1995) is different from ours.

In keeping with the observations on S. affinis (GabelDeickert, 1995), we did not find any correlation between egg size and clutch size, suggesting that female size is the main determinant of egg size.

Gabel-Deickert (1995) observed a tendency of egg volume increasing with female body size for eight species of Sepiolinae. This was also observed in S. atlantica. The relationship between female ML, egg volume, and egg weight found in this study has an interesting evolutive consequence. As maternal size increases, more reserves can be allocated to each egg, increasing the volume or weight of eggs. As a result, there may be direct effects of maternal size on individual offspring and consequently on the tradeoff between defence and offspring survivorship (GabelDeickert 1995; Goulden et al. 1987; Svensson and Sinervo 2000). It is this overall relationship that must be considered to predict reproductive strategies (Lessels 1991). As known from other taxonomic groups (e.g., thrips; Kranz 2005), these features are very important in sexual selection. More data are needed to address this problem.

Acknowledgments The authors appreciate the valuable help by Cristian Aldea (Foundation CEQUA, Chile) and Francisco Rocha (Department of Ecology and Animal Biology, University of Vigo). Special thanks to Gonzalo Giribet (Harvard University) and Fiona Read (ECOBIOMAR IIM/CSIC) for useful discussions improving the manuscript. The first author was supported by a scholarship from the Consellería de Educación e Ordenación Universitaria da Xunta de Galicia.

\section{References}

Arnold JM, Singley CT, Willians-Arnold LD (1972) Embryonic development and post-hatching survival of the sepiolid squid Euprymna scolopes under laboratory conditions. Veliger 14:361-364

Bello G, Deickert A (2003) Multiple spawning and spawning batch size in Sepietta oweniana (Cephalopoda: Sepiolidae). Cah Biol Mar 44:307-314

Bergström B, Summers WC (1983) Sepietta oweniana. In: Boyle PR (ed) Cephalopod life cycles. Species accounts, vol 1. Academic Press, London, pp 75-91

Beyer WH (1987) CRC standard mathematical tables, 28th edn. CRC Press, Boca Raton

Boletzky Sv (1975) The reproductive cycle of Sepiolidae (Mollusca, Cephalopoda). Pubbl Staz Zool Napoli 39(suppl):84-95

Boletzky Sv (1998) Cephalopod eggs and egg masses. Oceonogr Mar Biol Annu Rev 36:341-371

Boletzky Sv, Boletzky MVv, Frösch D, Gätzi V (1971) Laboratory rearing of Sepiolinae (Mollusca: Cephalopoda). Mar Biol 8:82-87

Gabel-Deickert A (1995) Reproductive patterns in Sepiola affinis and other Sepiolidae (Mollusca: Cephalopoda). In: Boletzky Sv (ed) Mediterranean Sepiolidae. Bulletin de L'Institut Océonographique, Monaco, $\mathrm{n}^{\circ}$ special 16, pp 73-83

Goulden CE, Henry L, Berrigan D (1987) Egg size, postembryonic yolk, and survival ability. Oecologia 72:28-31

Guerra A (1992) Mollusca, Cephalopoda. In: Ramos MA (ed) Fauna Ibèrica I. Museo Nacional de Ciencias Naturales CSIC, Madrid

Hanlon RT, Messenger JB (1996) Cephalopod behaviour. Cambridge University Press, UK

Hanlon RT, Claes MF, Ashcraft SE, Dunlap PV (1997) Laboratory culture of the sepiolid squid Euprymna scolopes: a model system for bacteria-animal symbiosis. Biol Bull 192:364-374

Harman RF, Young RE, Reid SB, Mangold KM, Suzuki T, Hixon RF (1989) Evidence for multiple spawning in the oceanic squid Stenoteuthis oualaniensis (Teuthoidea: Ommastrephidae). Mar Biol 101:513-519

Kranz BD (2005) Egg size and reproductive allocation in eusocial thrips. Behav Ecol 779-786

Lessels CM (1991) The evolution of life histories. In: Krebs JR, Davies NB (eds) Behavioural ecology: an evolutionary approach. Blackwell Scientific Publications, Oxford, pp 32-65

Mangold-Wirz K (1963) Biologie des cephalopods benthiques et nectoniques de la mer Catalane. Vie Milieu 13:1-285

Nabhitabhata J, Nilaphat P, Promboon P, Jaroongpattananon C (2005) Life cycle of cultured bobtail squid, Euprymna hyllebergi Nateewathana, 1997. Phuket Mar Biol Cent Res Bull 66:351-365 
Nigmatullin ChM (2002) Ovary development, potential and actual fecundity and oocyte resorption in coleoid cephalopods: a review. Berl Palaeobiologische Abh 1:82-84

Norman MD, Lu CC (1997) Redescription of the southern dumpling squid Euprymna tasmanica and a revision of the genus Euprymna (Cephalopoda: Sepiolidae). J Mar Biol Assoc UK 77:1109-1137

Rees WJ (1957) Mollusca: Cephalopoda. In: Plymouth marine fauna, 3rd edn. Marine Biological Association of United Kingdom, Plymouth, pp 339

Reid A, Jereb P (2005) Family Sepiolidae. In: Jereb P, Roper CFE (eds) Cephalopods of the world. An annotated and illustrated catalogue of species known to date I. Chambered nautiluses and sepioids (Nautilidae, Sepiidae, Sepiolidae, Sepiadariidae, Idiosepiidae and Spirulidae). FAO Species Catalogue for Fishery Purposes, Rome, pp 153-203
Rocha F, Guerra A, González AF (2001) A review of reproductive strategies in cephalopods. Biol Rev 76:291-304

Rodrigues M, Garcí ME, Guerra A, Troncoso JS (2009) Mating behavior of the Atlantic bobtail squid Sepiola atlantica (Cephalopoda: Sepiolidae). Vie Milieu 59:271-275

Svensson E, Sinervo B (2000) Experimental excursions on adaptive landscapes: density-dependent selection on egg size. Evolution 54:1396-1403

van Moorsel G (2004) Dwerginktvissen (Sepiolidae) in Nederland. Het Zeepard 64:78-91

Yau C, Boyle PR (1996) Ecology of Sepiola atlantica (Mollusca: Cephalopoda) in the shallow sublittoral. J Mar Biol Assoc UK 76:733-748 